\title{
ZNACZENIE UMÓW PRZEDWSTĘPNYCH W STOSUNKACH PRACY I ZAKRES SWOBODY KONTRAKTOWANIA STRON PRZY ICH ZAWIERANIU
}

\begin{abstract}
The importance of preliminary contracts in labor relations and the range of parties' contracting freedom at their conclusion

Labor legislation does not regulate separately the admissibility of preliminary employment contracts conclusion. Linguistic interpretation of the Article 389 of the Civil Code provides the arguments in favor of the idea of wide use of preliminary contracts in labor relations. This contract carries out the basic functions of labor law - by the fact that, on the one hand, secures and ensures employer with the needed workforce, on the other hand, provides to an employee desired employment in the future, i.e. legal and economic security of obtaining it in convenient for him - from the point of view of his career plans and family - time. Despite these clear benefits, the use of the preliminary contract in labor relations is relatively rare, i.e. the parties do not use the opportunity to conclude it. Meanwhile, this agreement should be a useful legal tool to obtain employees in deficit professions and in terms of lack of job candidates with necessary qualifications in the local market.
\end{abstract}

Słowa kluczowe: umowa o pracę, umowa przedwstępna, swoboda kontraktowa, termin zawarcia umowy o pracę, rodzaj pracy

Key words: employment contract, preliminary contract, contractual freedom, the term for conclusion of an employment contract, type of work

Ustawodawstwo pracy nie reguluje odrębnie dopuszczalności zawierania przedwstępnych umów o pracę. Wykładnia językowa art. 389 Kodeksu cywilnego (kc) dostarcza jednak argumentacji na rzecz poglądu o szerokim zastosowaniu w stosunkach pracy umowy przedwstępnej ${ }^{1}$. Umowa ta realizuje podstawowe funkcje prawa pracy - przez to, że, z jednej strony, zabezpiecza i gwarantuje pracodawcy potrzebną siłę roboczą, z drugiej, zapewnia pracownikowi w przyszłości pożądane zatrudnienie, tj. prawne i gospodarcze

1 Zob. E. Drozd, Umowa przedwstępna a umowa przyrzeczona, Nowe Prawo 1973, 11, s. 1561 oraz M. Gersdorf, Zawarcie umowy o prace, Warszawa 1985, s. 119-120. 
zabezpieczenie jego uzyskania i to w dogodnym dla niego, z punktu widzenia jego planów zawodowych i rodzinnych, czasie. Powstaje pytanie, dlaczego pomimo tych niewątpliwych korzyści, zastosowanie umowy przedwstępnej w stosunkach pracy występuje stosunkowo rzadko, tj. strony nie korzystają z możliwości ich zawierania. Zazwyczaj argumentuje się w to tym, że identyczny cel społeczno-gospodarczy można osiągnąć, zawierając - zamiast umowy przedwstępnej - „ostateczną” umowę o pracę, przewidując w niej późniejszy termin rozpoczęcia pracy, zgodnie $\mathrm{z}$ art. 26 Kodeksu pracy $(\mathrm{kp})$.

\section{Wprowadzenie}

Celem zawarcia umowy przedwstępnej, jako umowy samodzielnej, jest stworzenie stanu pewności, że określona, projektowana przez strony umowa,zostanie zawarta ${ }^{2}$. Umowa przedwstępna nie ma jednocześniecharakteru ostatecznego, lecz jedynie zobowiązuje jedną lub obie strony do zawarcia oznaczonej umowy (czynności o charakterze materialnym) w przyszłości. Zobowiązanie to jest treścią świadczenia w umowie przedwstępnej ${ }^{3}$ i odróżnia ją od umowy stanowczej, z której wynikają skutki o charakterze materialnoprawnym w zakresie konkretnego stosunku prawnego. W konsekwencji, umowa przedwstępna nie może być traktowana jak przyczyna prawna (causa solvendi) umowy definitywnej ${ }^{4}$.

W świetle art. $389 \$ 1$ kc umowa przedwstępna jest umową obligacyjną, znajdującą zastosowanie w procesie kontraktowania, w sytuacji gdy strony chcą zawrzeć umowę, lecz ten fakt, z różnych względów, innych jednak niż brak konsensusu co do istotnych postanowień umowy, odsuwają w czasie. Umowa przedwstępna należy zatem do umów o charakterze organizatorskim (przygotowawczym) ${ }^{5}$ i należy ją odróżnić od umowy definitywnej, która realizuje zamierzony przez strony cel społeczno-gospodarczy.

\section{Dopuszczalność zawierania umów przedwstępnych w stosunkach pracy}

\section{Rys historyczny}

Zagadnienie dopuszczalności umowy przedwstępnej w stosunkach pracy było przedmiotem rozważań w orzecznictwie Sądu Najwyższego już pod rządem art. 62 Kodeksu zobowiązań

2 Zob. wyrok SA w Poznaniu z 5 czerwca 2008 r., I ACa 204/08, nie publ.

3 Zob. wyrok SN z 11 kwietnia 2006 r., I CSK 175/05, nie publ. Por. także: J. Gwiazdomorski, Umowa przedwstępna w kodeksie zobowiązań, Czasopismo Prawnicze, t. XXX, Kraków 1936, s. 438 i n.; M. Krajewski, Umowa przedwstępna, Warszawa 2000 i Tenże, Wadliwości umowy przedwstępnej a umowa przyrzeczona, Monitor Prawniczy 2000, nr 5.

${ }_{4}$ G. Rudnicki, Umowa przedwstępna, w: S. Rudnicki, Prawo obrotu nieruchomościami, Warszawa 1995, s. 286 i A. Kondracka, Pojęcie i charakter prawny umowy przedwstępnej, Monitor Prawniczy 1999, 3, s. 12.

5 Zob. wyrok SA w Krakowie z 21 października 2015 r., I ACa 928/15, Legalis, nr 1399133. 
$(\mathrm{kz})^{6}$. W orzeczeniu z 6 października1961 $\mathrm{r}^{7}$ Sąd, rozstrzygając w sensie pozytywnym wspomnianą wątpliwość, wypowiedział pogląd, że zawarcie umowy przyrzeczonej może być przymusowo realizowane na podstawie przepisu art. $62 \S 3 \mathrm{kz}$, i to bez względu na to, czy umowa przedwstępna została zawarta z zachowaniem określonej formy, czy nawet ustnie, dla zawarcia bowiem umowy o pracę ustawa nie przewiduje szczególnej formy. W doktrynie, z kolei, wskazywano, że obowiązek zawarcia umowy o pracę może wynikać z umowy przedwstępnej, musi ona jednak określać istotne postanowienia i termin zawarcia przyszłej umowy.

W omawianym zakresie szczególne unormowania przewidywały ustawy: z 25 lutego 1964 r. o zatrudnianiu absolwentów szkół wyższych oraz orzekaniu o obowiązku zwrotu kosztów wykształcenia ${ }^{9}$ (obowiązująca nadal po wejściu w życie Kodeksu pracy - art. VII pkt 17 Przepisów wprowadzających Kodeks pracy (pwkp) ${ }^{10}$, zwana dalej „ustawą z 1964 r.”), a następnie z 14 grudnia 1982 r. o zatrudnianiu absolwentów ${ }^{11}$ (zwana dalej „ustawą z 1982 r.") oraz odpowiednio rozporządzenia Rady Ministrów: z 13 czerwca 1964 r. w sprawie zatrudniania absolwentów szkół wyższych oraz orzekania o obowiązku zwrotu kosztów wykształcenia $^{12}$, a następnie z 31 sierpnia $1983 \mathrm{r}$. w sprawie zatrudniania absolwentów ${ }^{13}$, przewidujące możliwość zawierania umów przedwstępnych o pracę przez studentów z zakładami pracy objętymi planem zatrudniania absolwentów, a także określających skutki uchylania się stron od zawarcia przyrzeczonej umowy o pracę ${ }^{14}$. Ustawa z $1964 \mathrm{r}$. dopuszczała zawieranie z absolwentami szkół wyższych umów przedwstępnych i umów o stypendium fundowane, które były szczególnym rodzajem umów przedwstępnych. Umowa przedwstępna stanowiła w tym zakresie formę rozdziału absolwentów kierunków studiów, którzy zostali objęci planowym zatrudnieniem. Z kolei ustawa z 1982 r. swoim zakresem podmiotowym objęła absolwentów wszystkich rodzajów szkół. W pełni realizując zasadę swobody nawiązania stosunku pracy, zrezygnowała z mechanizmów krępujących absolwentów niektórych kierunków studiów szkół wyższych w wyborze miejsca pracy, ale w dalszym ciągu przewidywała dwa rodzaje umów odnośnie do przyszłego zatrudnienia: przedwstępną i o stypendium fundowane (art. 2 ust. 1). Absolwent, z którym zawarto umowę przedwstępną, był obowiązany: (1) zgłosić się do zakładu pracy w celu podjęcia pracy w terminie określonym w umowie przedwstępnej albo (2) wypłacić zakładowi pracy

6 Kodeks zobowiązań - Rozporządzenie Prezydenta RP z 27 października 1933 r.(Dz. U. z 1933 r., $\mathrm{Nr}$ 82, poz. 598).

7 I CR 1006/61, nie publ. Zob. także wyrok z 30 listopada 1961 r., 4 CR 722/61, OSNCP 1963, z. 7-8, poz. 145 .

8 M. Święcicki, Prawo pracy, Warszawa 1968, s. 160.

9 Dz. U. z 1964 r., Nr 8, poz. 46.

10 Ustawa z 26 czerwca 1974 r. Przepisy wprowadzające Kodeks pracy (Dz. U. 1974, Nr 24, poz. 142).

11 Dz. U. z 1982 r., Nr 40, poz. 270 - art. 2 ust. 1 pkt 2.

12 Dz. U. z 1972 r., Nr 2, poz. 9.

13 Dz. U. z 1983 r.,Nr 53, poz. 234.

14 Szerzej M. Gersdorf, Zawarcie umowy..., s. 120-124; A. Kałuziński, Pojęcie, funkcje, charakter prawny umowy o stypendium fundowane, Państwo i Prawo 1968, 8-9, s. 870 i A. Malanowski, Niektóre problemy prawne skierowania do pracy absolwentów szkół wyższych, Państwo i Prawo 1966, 2, s. 299. 
odszkodowanie przewidziane $\mathrm{w}$ umowie przedwstępnej $\mathrm{w}$ razie niepodjęcia pracy w terminie określonym w umowie. Oznacza to, że na treść przedwstępnej umowy o pracę składały się postanowienia określające termin zawarcia definitywnej umowy o pracę oraz wysokość odszkodowania należnego stronie, której kontrahent odmówił zawarcia umowy przyrzeczonej, przy pominięciu uzgodnień dotyczących innej, choćby minimalnej treści przyszłej umowy (poza ogólnym obowiązkiem zatrudnienia absolwenta zgodnie z kierunkiem wykształcenia). Jedynie z przepisów rozporządzenia z 1983 r. można było wyprowadzić wniosek, że w umowie przedwstępnej i o stypendium fundowane, kontrahenci są zobowiązani do określenia stanowiska, na którym będzie w przyszłości zatrudniony pracownik-absolwent ( $\$ 3$ rozporządzenia).

W odniesieniu do innych osób (niebędących absolwentami) podstawy prawnej do zawierania przedwstępnych umów o pracę dopatrywano się $\mathrm{w}$ stosowanych posiłkowo przepisach prawa cywilnego (art. 389-390 kc w związku z art. XII $\$ 3$ Przepisów wprowadzających Kodeks cywilny [pwkc] ${ }^{15}$ ), a nie w wyżej wymienionych regulacjach dotyczących zatrudniania absolwentów, które uznawano za mające charakter wyjątkowy i szczególny, o istotnie ograniczonym zakresie podmiotowym ${ }^{16}$. Takiemu stanowisku Sąd Najwyższy (SN) dał wyraz m.in. w uchwałach: z 21 czerwca 1972 r. ${ }^{17}$ oraz z 26 lipca $1974 \mathrm{r}^{18}$, a po wejściu w życie Kodeksu pracy zostało ono podtrzymane w orzeczeniach: z 29 sierpnia $1975 \mathrm{r}^{19}$ oraz z 2 października $1975 \mathrm{r}^{20}$ Sprawy o roszczenia wynikające z tych umów, w tym o nawiązanie stosunku pracy, były i są sprawami ze stosunku pracy ${ }^{21}$ $\mathrm{w}$ rozumieniu art. XII pwkc i art. $459 \$ 1$ Kodeksu postępowania cywilnego $(\mathrm{kpc})^{22}$.

\section{Obowiązujący stan prawny}

Możliwość zawierania przedwstępnych umów o pracę, bez ograniczeń o charakterze podmiotowym, jest od wielu lat powszechnie akceptowana w doktrynie oraz w orzecznictwie, przy założeniu, że nie pozostaje w sprzeczności z żadną z zasad prawa pracy ${ }^{23}$. Ponadto jest potwierdzeniem istnienia w stosunkach pracy swobody kontraktowania.

15 Ustawa z 23 kwietnia 1964 r. (Dz.U. z 2017 r., poz. 459 - tekst jedn.).

16 Tak M. Gersdorf, Zawarcie umowy..., s. 127-128.

17 III PZP 13/72, OSNCP 1972, z. 12, poz. 201.

18 III PZP 22/74, OSNCP 1975, z. 2, poz. 23.

19 I PR 120/75, nie publ.

20 I PRN 21/75, OSPiKA 1976, z. 9, poz. 167. Zob. także orzeczenie SN z 30 listopada 1961 r., 4 CR 722/61, OSNCP 1963, nr 7-8, poz. 148.

${ }^{21}$ Zob. ww. uchwałę SN z 26 lipca 1974 r., uchwałę 7 SN z 31 marca 1967 r., OSNCP 1967, z. 9, poz. 150, post. SN z 2 października 1975 r., ww. oraz wyrok SN z 19 stycznia 1998 r., I PKN 482/97, OSNP 1998, nr 23, poz. 686. jedn.).

22 Ustawa Kodeks postępowania cywilnego z 17 listopada 1964 r. (Dz.U. z 2016 r., poz. 1822 - tekst

23 Por. wyrok SN z 13 maja 1977 r., I PZ 23/77, OSPiKA 1979, nr 3, poz. 47. Przydatność umowy przedwstępnej podaje w wątpliwość W. Muszalski, Przedwstępna umowa o pracę czy zbędna konstrukcja 
Co więcej, taka umowa realizuje dwie funkcje prawa pracy: organizacyjną i ochronną, przez fakt, iż - z jednej strony - zapewnia zakładowi pracy niezbędną siłę roboczą, a z drugiej - zabezpiecza pracownikowi pożądane i oczekiwane zatrudnienie. Podkreśla się, że umowy przedwstępne mogą być skutecznym instrumentem kształtowania stosunku pracy z punktu widzenia polityki zatrudnienia ${ }^{24}$. Podstawę prawną ich stosowania, jak już wskazano, stanowią art. 389-390 kc w związku z art. $300 \mathrm{kp}^{25}$.

Nie budzi wątpliwości teza, iż umowy przedwstępne mogą występować w umownych stosunkach pracy, uzasadnione wątpliwości dotyczą natomiast innych - poza umową o pracę - sposobów jego nawiązania ${ }^{26}$. Stosowanie umowy przedwstępnej do pozaumownych stosunków pracy powinno być uznane za sprzeczne z ich istotą. Zasadniczą przeszkodą pozostaje w tym względzie status pracodawcy bądź też innego podmiotu podejmującego decyzję w przedmiocie nawiązania stosunku pracy, a w przypadku powołania dochodzi dodatkowo element administracyjnoprawny związany z samym aktem powołania. Sąd Najwyższy w uchwale z 4 maja 1979 r. ${ }^{27}$ zajął stanowisko, które należy podzielić, że osobie, wobec której nie dotrzymano przyrzeczenia nawiązania stosunku pracy na podstawie powołania, nie przysługuje z tego tytułu roszczenie o nawiązanie takiego stosunku. Wykluczone pozostaje zatem stosowanie przedwstępnych umów (zobowiązań) o pracę.

Umowa przedwstępna nie ma charakteru ostatecznego, lecz jedynie zobowiązuje jedną lub obie strony do zawarcia oznaczonej umowy w przyszłości. Postanowienia tej umowy nie mogą być jednak traktowane jako odrębna klauzula w umowie o pracę zawartej w jej wykonaniu, chyba że zostaną przeniesione do treści tej umowy ${ }^{28}$. Przedmiotem umowy przedwstępnej może być przyrzeczenie zawarcia każdej umowy, w tym umowy o pracę zmieniającej treść stosunku pracy oraz rozwiązującej go. Oświadczenie pracodawcy stanowiące ofertę zawarcia umowy przedwstępnej musi być skierowane do przyszłego pracownika. Wynika to z treści art. $66 \$ 1 \mathrm{kc} \mathrm{w}$ związku z art. $300 \mathrm{kp}$, w myśl którego oświadczenie drugiej stronie woli zawarcia umowy stanowi ofertę, jeżeli określa istotne postanowienia tej umowy. Zatem, jeżeli oświadczenie woli zawarcia umowy przedwstępnej było skierowane nie do przyszłego pracownika, lecz do innej osoby lub osób (np. publicznie, w ofercie zatrudnienia), to nie może ono stanowić podstawy do uznania, że w ten sposób złożono pracownikowi ofertę zawarcia umowy przyrzeczonej. Wszelkiego rodzaju deklaracje negocjacyjne czy też inne zapewnienia nawiązania stosunku pracy,

prawna, Praca i Zabezpieczenie Społeczne 1999, 3, s. 38 i n. Zob. także B. Bury, Odpowiednie stosowanie w prawie pracy wybranych przepisów Księgi III Kodeksu cywilnego, Monitor Prawa Pracy 2007, 5, s. 230 i n.

24 Zob. B. Wagner, Zakres swobody umów w pracowniczym stosunku pracy, Kraków 1986, s. 163.

25 Zob. M. Gersdorf-Giaro, Umowa przedwstępna w prawie pracy, Państwo i Prawo 1979, 11, s. 79 i n.; Taż, Zawarcie umowy..., s. 124 i n. Por. także wyroki SN: z 15 marca 1977 r., I PRN 22/77, MP 2000, nr 4, s. 264, z 2 października 1975 r., ww. i z 22 kwietnia 1977 r., I PZP 5/77, OSN 1977, z. 10, poz. 180.

${ }_{26}$ Tak T. Liszcz, Prawo pracy, Warszawa 2009, s. 138 oraz R. Sadlik, Umowa przedwstępna poprzedzajaca zawarcie umowy o pracę, Monitor Prawa Pracy 2008, 5, s. 246. Odmiennie H. Szewczyk, Umowa przedwstępna w polskim prawie pracy, Z Problematyki Prawa Pracy i Polityki Socjalnej, Katowice 2001, 14, s. 43.

27 I PZP 5/79, OSPiKA 1980, nr 2, poz. 20 z krytyczną glosą A. Kijowskiego.

28 Zob. wyrok SN z 9 lutego 2000 r., I PKN 528/99, OSNP 2001, nr 13, poz. 437. 
zawierające wyraz woli dążenia przez kontrahentów do zawarcia umowy o pracę, bez doprecyzowania jednak jej przyszłych postanowień, nie są umowami przedwstępnymi ${ }^{29}$.

Świadczenie stanowiące wykonanie zobowiązania $\mathrm{z}$ umowy przedwstępnej polega na zawarciu definitywnej umowy o pracę. Powracając do poglądu, że identyczny cel społeczno-gospodarczy można osiągnąć, zawierając - w miejsce umowy przedwstępnej - umowę o pracę, przewidując w niej późniejszy termin rozpoczęcia pracy, zgodnie $\mathrm{z}$ art. $26 \mathrm{kp}^{30}$, należy podkreślić, że nie zasługuje on na akceptację. Różnica polega na tym, że gdy dochodzi do zawarcia definitywnej umowy o pracę, z chwilą nadejścia terminu, określonego w niej jako termin rozpoczęcia pracy, każda ze stron może żądać wykonania wszelkich zobowiązań (świadczeń) wynikających ze stosunku pracy. Ponadto działania obu kontrahentów w przypadku takiej umowy powinny być oceniane z punktu widzenia przepisów prawa pracy regulujących umowę o pracę, np., gdyby pracownik nie podjął pracy, pracodawca mógłby rozwiązać umowę o pracę bez wypowiedzenia, traktując zachowanie pracownika jako ciężkie naruszenie podstawowych obowiązków pracowniczych (art. $52 \$ 1$ pkt $1 \mathrm{kp}$ ), z kolei pracownik mógłby żądać dopuszczenia do pracy. Taka kwalifikacja byłaby natomiast nieuprawniona, gdyby strony były związane jedynie umową przedwstępną. Wówczas bowiem nienawiązanie stosunku pracy w umówionym terminie i niestawiennictwo do pracy można by oceniać jedynie z punktu widzenia niewykonania zobowiązania złożenia oznaczonego oświadczenia woli. Rygory niewykonania świadczenia $z$ umowy przedwstępnej są zatem uregulowane odrębnie, w Kodeksie cywilnym, stosowanie do celu tej umowy ${ }^{31}$. Akceptacja stanowiska A. Mirończuka oznaczałaby, w konsekwencji, zanegowanie przydatności umowy przedwstępnej na gruncie stosunków pracy, której następstwa niewykonania nie wywołują tak daleko idących skutków jak umowy definitywnej.

Umowa przedwstępna może być dwu- lub jednostronnie zobowiązująca. W doktrynie budzi wątpliwości dopuszczalność jednostronnego zobowiązania się pracownika w szczególności do nawiązania w przyszłości stosunku pracy ${ }^{32}$. Wskazuje się w tym względzie na bezprzedmiotowość takiej umowy wobec niemożności skutecznego dochodzenia przez pracodawcę zawarcia przyrzeczonej umowy o pracę z uwagi na ograniczenie wolności pracy (art. $10 \mathrm{kp}$ ). Wówczas powstałby taki skutek, że dopuszczalne byłyby umowy przedwstępne zobowiązujące do zawarcia przyszłych umów stanowczych wyłącznie pracodawcę ${ }^{33}$. Zdaniem B. Wagner ${ }^{34}$ jednostronne zobowiązanie się pracownika do zawarcia w przyszłości umowy o pracę nie prowadzi do ograniczenia jego wolności

29 Zob. R. Sadlik, Umowa przedwstępna..., s. 244. Zob. także wyrok SA w Katowicach z 14 stycznia 2000 r., I ACa 914/99, OSA 2001, nr 2, poz. 8.

30 A. Mirończuk, Glosa do wyroku SN z 2 października 1975 r., I PRN 21/75, OSPiKA 1976, nr 9 , poz. 167 i s. 388.

31 M. Gersdorf, Zawarcie umowy..., s. 129-130 i A. Kijowski, Pracowniczy obowiązek gotowości do świadczenia pracy, Poznań 1978, s. 65.

32 M. Gersdorf-Giaro, Umowa przedwstępna..., s. 83 i Taż, Zawarcie umowy..., s. 134.

33 Tak, jak się wydaje, T. Liszcz, Prawo..., s. 141.

34 B. Wagner, Zakres swobody umów..., s. 165. 
pracy, albowiem obowiązek nawiązania stosunku pracy lub pozostawania w nim ma swoje źródło w woli pracownika, tj. w jego dobrowolnym zobowiązaniu. M. Gersdorf ${ }^{35}$ zwraca uwagę, że dochodzeniu zawarcia umowy przyrzeczonej w takim przypadku przeciwstawiają się zasady prawa pracy, zwłaszcza zasada dobrowolności zatrudnienia, wyrażona w art. $11 \mathrm{kp}$, i że w takiej sytuacji praktycznym skutkiem zawarcia umowy o pracę byłaby ewentualna możliwość oceny zachowania pracownika w kategoriach nieistniejącej instytucji porzucenia pracy, a interes pracodawcy i tak nie zostałby zaspokojony.

Należy zgodzić się z poglądem, że roszczenie pracodawcy o zawarcie umowy o pracę nie będzie mogło być zaspokojone i nie będzie on mógł dochodzić nawiązania stosunku pracy; pracodawca bowiem, nawet przy założeniu istnienia orzeczenia sądowego w tym przedmiocie, nie dysponuje środkami prawnymi przymuszającymi pracownika do świadczenia pracy ${ }^{36}$. Mógłby jednak sformułować roszczenie odszkodowawcze, w związku z tym, takie zobowiązanie należy uznać zarówno za dopuszczalne, jak i celowe. Jak trafnie podnosi się w doktrynie i orzecznictwie, przyczyną prawną zawarcia umowy przedwstępnej są przyszłe korzyści wynikające z umowy przyrzeczonej, a nie oczekiwanie na zobowiązanie się drugiej strony do zawarcia takiej umowy ${ }^{37}$. Nawet więc gdy obie strony umowy przedwstępnej zobowiązują się do złożenia oświadczenia woli o zawarciu umowy przyrzeczonej, ich świadczenia nie mają charakteru świadczeń wzajemnych w rozumieniu art. $487 \$ 2 \mathrm{kc}$. W konsekwencji żądanie pracodawcy zawarcia przyrzeczonej umowy o pracę nie jest sprzeczne z prawem, zasadą swobody nawiązywania stosunku pracy, jak również z zasadami współżycia społecznego.

\section{Forma i treść przedwstępnej umowy o pracę}

Umowa o pracę, zgodnie $\mathrm{z}$ art. $29 \$ 2 \mathrm{kp}$, powinna być zawarta w formie pisemnej, umowa przedwstępna zobowiązująca do jej zawarcia może być jednak zawarta w formie ustnej lub innej dowolnej formie, żaden bowiem przepis prawa nie określa wymogów co do jej formy. Decyzja stron w tym zakresie ma jedynie znaczenie przy określaniu jej skutków oraz w postępowaniu dowodowym (art. 74 kc w związku z art. $300 \mathrm{kp}$ ), zarówno co do samego faktu zawarcia tej umowy, jak i jej treści ${ }^{38}$.

Określenie istotnych postanowień umowy przyrzeczonej, a zwłaszcza ich zakresu, ma bardzo duże znaczenie dla wyjaśnienia zagadnienia stosunku treści umowy przedwstępnej do treści umowy przyrzeczonej. Przepis art. 389 kc wymaga, aby umowa przedwstępna określała „istotne postanowienia umowy przyrzeczonej”, nie precyzując bliżej, jak to

${ }^{35}$ M. Gersdorf, Zawarcie umowy...,s. 133-134.

36 A. Kurzych, Odszkodowanie z tytułu niewykonania pracowniczej umowy przedwstępnej, Monitor Prawa Pracy 2010, 3, s. 125.

37 Por. wyrok SN z 14 grudnia 1999 r., II CKN 624/98, OSNC 2000, nr 6, poz. 120.

38 W. Masewicz, Glosa do uchwaly SN z 22 kwietnia 1977 r., I PZP 5/77, OSPiKA 1978, nr 5, poz. 98, s. 230-231. 
należy rozumieć. W literaturze przedmiotu wyróżnia się wiele kryteriów istotności postanowień, w zależności m.in. od płaszczyzny, w jakiej się je rozpatruje. Najbardziej znany jest podział składników treści czynności prawnych na elementy przedmiotowo istotne (essentialia negotii), podmiotowo istotne (accidentalia negotii) oraz nieistotne (naturalia negotii $)^{39}$. Z punktu widzenia pochodzenia składnika treści czynności prawnej można dokonać podziału na składniki pochodzące od stron ( $\mathrm{w}$ tradycyjnym podziale: essentialia negotii i accidentalia negotii) oraz wynikające z przepisów względnie obowiązujących ustawy, zasad współżycia społecznego i ustalonych zwyczajów ( $w$ tradycyjnym podziale: naturalia negotii).

Na gruncie umowy przedwstępnej, zawieranej na podstawie stosunków pracy, konieczne jest uwzględnienie specyfiki umowy o pracę, tzn. w umowie tej powinna być określona tylko tzw. minimalna treść umowy przyrzeczonej ${ }^{40}$. Z kolei konieczną treść umowy o pracę wyznaczają takie elementy, jak: strony umowy i rodzaj pracy (postanowienia, bez wyrażenia których w oświadczeniu woli czynność prawna w ogóle nie dochodzi do skutku, indywidualizujące ją, klauzule umowy, w tradycyjnym podziale: essentialia negotii).Należy pamiętać, że z kolei umowa przedwstępna nie stawia takich wymagań co do kompletności regulacji umownej jak umowa przyrzeczona. Umowa przyrzeczona powinna być wystarczająco określona w umowie przedwstępnej. Dla spełnienia tego wymagania konieczne jest, jeżeli umowa przedwstępna będzie zawierała taką miarę określoności, aby - w przypadku sporu - treść umowy przyrzeczonej mogła zostać ustalona na drodze wykładni umowy przedwstępnej ${ }^{41}$. W pewnych przypadkach niektóre postanowienia będą mieć dla stron jednakową wagę jak postanowienia konstytutywne (essentialia negotii ${ }^{42}$. Zakres istotnych postanowień, będących przedmiotem uzgodnień stron, będzie zależał zatem nie tylko od rodzaju umowy stanowczej, ale również od tego, które z elementów jej treści strony uznają za istotne ${ }^{43}$. $Z$ istoty przedwstępnej umowy o pracę wynika konieczność określenia w niej elementów przedmiotowo istotnych umowy przyrzeczonej, tj. stron przyszłej umowy o pracę oraz rodzaju pracy. Dodatkowo chodzi ewentualnie o postanowienia tego rodzaju, że bez porozumienia się co do nich strony (lub przynajmniej jedna z nich) nie chciałyby zawrzeć umowy przyrzeczonej, np. wysokość wynagrodzenia za pracę, wymiar czasu pracy, czyli takich, które z punktu widzenia prawa pracy mają charakter względnie obligatoryjny. Oznacza to połączenie stanowiska stron oraz zapatrywań obrotu prawnego. Jeżeli z wyraźnych oświadczeń stron lub z okoliczności wynika, że dane postanowienie stanowi przynajmniej dla jednej ze stron conditio sine qua non zawarcia umowy przyrzeczonej, to jest to postanowienie

39 Szerzej J. Strzępka, Umowy przedwstępne w obrocie uspołecznionym, Warszawa 1978, s. 25 i n.

40 Por. E. Drozd, Umowa przedwstęnna..., s. 1564.

41 Zob. wyroki SN: z 11 kwietnia 2006 r., I CSK 175/05, Lex nr 424367 oraz z 10 września 1997 r., I PKN 243/97, OSNAPiUS 1998, nr 12, poz. 357.

42 Tamże, s. 27-27.

43 Zob. R. Sadlik, Umowa przedwstępna..., s. 244. 
istotne. Musi więc być ono określone w umowie przedwstępnej, aby kontrahent był zobowiązany do wyrażenia zgody na jego zamieszczenie w umowie przyrzeczonej ${ }^{44}$.

Mając zatem na względzie istotę umowy o pracę, umowa przedwstępna zobowiązująca do zawarcia (w przyszłości) umowy o pracę powinna zawierać: strony umowy, określenie rodzaju przyszłej pracy ${ }^{45}$ oraz ewentualnie inne postanowienia umowy przyrzeczonej uznane przez strony za konieczne. Wątpliwości dotyczą tego, czy wśród nich mieszczą się wskazanie terminu zawarcia umowy właściwej ${ }^{46}$, wynagrodzenie ${ }^{47}$ oraz ewentualnie inne elementy. Według W. Masewicza ${ }^{48}$ do koniecznych warunków umowy przedwstępnej należy określenie rodzaju umowy, rodzaju pracy i terminu jej rozpoczęcia oraz wynagrodzenia odpowiadającego rodzajowi pracy. Ten pogląd, moim zdaniem, mógłby znaleźć akceptację jedynie wówczas, gdyby przed zawarciem umowy przedwstępnej strony prowadziły rokowania co do powyższych elementów. Istotą umowy przedwstępnej jest bowiem zobowiązanie się stron do złożenia w określonym terminie oświadczeń woli w przedmiocie stosunku pracy, w tym w zakresie jego nawiązania, $\mathrm{z}$ uwzględnieniem co najmniej postanowień koniecznych w rozumieniu regulacji prawa pracy, tj. rodzaju pracy - w odniesieniu do nawiązania umowy o pracę, elementu podlegającego zmianie, np. czasu pracy, miejsca pracy itp. - w przypadku umowy zmieniającej bądź też elementu istotnego z punktu widzenia bytu stosunku pracy - w odniesieniu do umowy rozwiązującej. W pozostałym zakresie decydujące znaczenie należy przypisać woli stron. Chodzi o elementy mające takie znaczenie dla stron, że bez nich umowa przyrzeczona nie zostałaby zawarta. Decyduje zatem, poza elementami koniecznymi, w istocie kryterium subiektywne, a nie obiektywne ${ }^{49}$.

W ww. wyroku z 10 września 1997 r. SN wyraził pogląd, że jeżeli nie doszło do zawarcia umowy przedwstępnej, bo rokowania stron nie czynią zadość wymaganiom art. 389 kc i nie ustalają istotnych postanowień, o których mowa w art. $29 \$ 1$ pkt 1 i 2 kp, to żadna ze stron pertraktacji nie jest uprawniona do dochodzenia zawarcia umowy o pracę na podstawie art. $390 \$ 2 \mathrm{kc}$ w związku z art. $300 \mathrm{kp}$. Z kolei w wyroku z 15 listopada $2016 \mathrm{r}^{50}$ Sąd Najwyższy wskazał, że strony mogą do treści umowy przedwstępnej (art. 389 kc) wprowadzić w granicach określonych w art. $353^{1} \mathrm{kc}$ postanowienia, które nie przesądzają o jej bycie, nie stanowią o jej skuteczności i nie odnoszą się do spełnienia świadczenia $\mathrm{z}$ tej umowy (zawarcie umowy przyrzeczonej), ale kształtują zachowania stron w okresie

44 E. Drozd, Umowa przedwstępna..., s. 1564-1565.

${ }_{45}$ Tak M. Gersdorf, Zawarcie umowy..., s. 131; W. Szubert, Zarys prawa pracy, Warszawa 1976, s. 111; T. Zieliński, Zarys wykładu prawa pracy, cz. II, Katowice 1978, s. 16 i Z. Salwa, Rola umowy w kształtowaniu stosunku pracy, Państwo i Prawo 1977, 11, s. 29.

46 Tak T. Liszcz, Zmiana zatrudnienia w wyniku porozumienia zakładów pracy, Nowe Prawo 1977, 5, s. 65.

47 M. Masewicz, Glosa do uchwaty SN z 22 kwietnia 1977 r., s. 230 i n.; podobnie J. Kruszewska, Skutki prawne przyrzeczenia zawarcia umowy o pracę, Przegląd Ustawodawstwa Gospodarczego 1979, 3, poz. 72.

${ }^{48}$ M. Masewicz, Glosa do uchwaty SN z 22 kwietnia 1977 r., s. 230.

49 Zob. E. Drozd, Umowa przedwstępna..., s. 1566 oraz M. Gersdorf, Zawarcie umowy ..., s. 131-132 i J. Strzępka, Umowy przedwstępne..., s. 28-31.

50 III CNP 9/16, Legalis, nr 1533479. 
poprzedzającym zawarcie umowy przyrzeczonej. Do takich postanowień należą m.in. określenie zobowiązania jednej ze stron do spełnienia świadczenia z umowy przyrzeczonej.

Granice swobody stron w określaniu przyszłej umowy o pracę zostały wyznaczone analogicznie jak zakres swobody kontraktowania co do jej treści istniejący w chwili zawarcia tej umowy, bez poprzedzania jej umową przedwstępną. Obejmuje zatem strony umowy oraz rodzaj pracy. Dopuszczalne jest również zawarcie umowy przedwstępnej zobowiązującej do zawarcia kolejnej umowy przedwstępnej, tworzącej jedynie skutki obligacyjne dla obu stron (art. $389 \mathrm{kc})^{51}$. Możliwa będzie zatem taka sekwencja umów, w której pierwsza umowa przedwstępna obliguje strony lub jedną z nich do zawarcia innej umowy przedwstępnej jako umowy przyrzeczonej, a z kolei ta umowa przedwstępna może zawierać zobowiązanie również obu lub jednej strony do zawarcia określonej umowy definitywnej. Nie ma przeszkód, aby umowa przedwstępna, obligująca do zawarcia kolejnej umowy przedwstępnej, zawierała treść zbliżoną lub identyczną z zawartą następnie drugą umową przedwstępną jako umową przyrzeczoną.

\section{Problematyka terminu zawarcia umowy stanowczej}

We wcześniejszym orzecznictwie oraz literaturze przedmiotu ${ }^{52}$ do elementów przedmiotowo istotnych umowy przedwstępnej zaliczano uzgodnienie terminu, w ciągu którego umowa stanowcza ma być zawarta (art. $389 \$ 2 \mathrm{kc}$ ), rodzącego dla jednej lub obu stron obowiązek zawarcia najpóźniej w tym terminie umowy przyrzeczonej. Termin ten mógł być określony jednoznacznie i bezpośrednio (niekoniecznie datą kalendarzową) ${ }^{53}$ lub pośrednio - poprzez wskazanie zdarzenia przyszłego i pewnego. W tym drugim przypadku termin wystąpienia zdarzenia wyznaczającego zawarcie przyrzeczonej umowy o pracę musiał być konkretny i znany stronom przynajmniej w przybliżeniu ${ }^{54}, \mathrm{z}$ możliwością jego zmiany na drodze umowy oraz niedopuszczalnością jego przedłużenia na czas nieoznaczony ${ }^{55}$. Argumentowano, że wskazanie terminu zawarcia umowy stanowczej ma sprzyjać zachowaniu zasady pewności obrotu oraz zapewniać możliwość dochodzenia roszczeń wynikających $\mathrm{z}$ umowy przedwstępnej. Gdyby termin ten nie został oznaczony, uprawniony mógłby się domagać zawarcia umowy przyrzeczonej niezwłocznie, na podstawie art. $455 \mathrm{kc}$, co mijałoby się z celem umowy przedwstępnej. Dodatkowo, bezterminowe zobowiązanie do zawarcia umowy przyrzeczonej byłoby szkodliwe dla obrotu, gdyż strony byłyby bezterminowo związane obowiązkiem zawarcia umowy przyrzeczonej w każdej chwili na żądanie drugiej strony. Takie bezterminowe związanie stron umową przedwstępną

51 Zob. wyrok SN z 28 października 2010 r., II CSK 219/10, OSNC 2011, nr 6, poz. 73.

52 J. Strzępka, Umowy przedwstępne...,s. 31 i n.

53 Por. orzeczenia SN: z 8 lipca 1963 r., III CR 161/63, OSNCP 1964, nr 7-8, poz. 152 i z 14 grudnia 1972 r., III CRN 331/72, OSPiKA 1973, nr 10, poz. 195.

${ }_{54}$ Zob. wyrok SN z 14 grudnia 2004 r., II PK 108/04, OSNP 2005, nr 15, poz. 223. Zob. także wyrok SN z 19 stycznia 1998 r., I PKN 482/97, OSNAPiUS 1998, nr 23, poz. 686.

55 Zob. A. Kondracka, Pojęcie i charakter..., s. 12. 
ograniczałoby swobodę zawierania umów na czas nieokreślony. Jeżeli bowiem termin, w ciągu którego ma być zawarta umowa przyrzeczona, nie został oznaczony, powinna ona być zawarta w odpowiednim terminie wyznaczonym przez stronę uprawnioną do żądania zawarcia umowy przyrzeczonej. Jeżeli obie strony są uprawnione do żądania zawarcia umowy przyrzeczonej i każda z nich wyznaczyła inny termin, strony wiąże termin wyznaczony przez stronę, która wcześniej złożyła stosowne oświadczenie. Jeżeli w ciągu roku od dnia zawarcia umowy przedwstępnej nie został wyznaczony termin do zawarcia umowy przyrzeczonej, nie można żądać jej zawarcia. Zasada ta ma istotne znaczenie z punktu widzenia art. $26 \mathrm{kp}$, gdyż z terminem zawarcia umowy pozostaje w ścisłym związku termin nawiązania stosunku pracy. W każdej sytuacji nie może to być termin zbyt odległy i wymaga indywidualizacji. Analiza przepisów prawa pracy regulujących skutki upływu czasu i jego wpływ na stosunek pracy prowadzą do wniosku, że intencją ustawodawcy jest wprawdzie zagwarantowanie podmiotom prawa pewności ich sytuacji prawnej i stabilizacji w stosunkach zatrudnienia, ale tylko rzeczywistej, a nie jedynie formalnej. Przeciwko nadmiernemu wydłużaniu takiej formalnej stabilizacji świadczyły kiedyś regulacje art. $33 \mathrm{kp}$ (o dopuszczalności wypowiadania umów o pracę na czas określony dłuższy niż 6 miesięcy) czy też o ograniczeniu obowiązku przepracowania w pewnych sytuacjach okresu do 3 lat (umowy przedwstępne ze studentami/uczniami ostatnich lat nauki). Potrzebę pewności sytuacji prawnej podmiotów stosunku pracy potwierdzają również przepisy regulujące problematykę czasu postępowania w sporach ze stosunku pracy ${ }^{56}$.

W judykaturze podkreśla się, że instytucja umowy przedwstępnej, przygotowując zawarcie umowy definitywnej, pełni nie tylko funkcję pomocniczą, lecz także funkcję gwarancyjną, przez zapewnienie (po spełnieniu określonych wymagań) dojścia do skutku umowy przyrzeczonej. Oznaczenie terminu jako niezbędnego elementu w treści umowy przedwstępnej ma na celu ograniczenie do określonych ram czasowych stanu niepewności co do istnienia stosunku prawnego. Nieograniczona w czasie niepewność co do związania umową budziłaby wątpliwości i niepewność przede wszystkim z punktu widzenia zasady ochrony bezpieczeństwa prawnego ${ }^{57}$. Określony przez strony termin zawarcia umowyprzyrzeczonej nie jest terminem końcowym, a jedynie terminem spełnienia świadczenia, którego upływ nie powoduje wygaśnięcia zobowiązania do zawarcia umowy przyrzeczonej ${ }^{58}$. Przeciwnie, upływ tego terminu skutkuje wymagalnością roszczenia o zawarcie umowy, a konsekwencją tego jest rozpoczęcie biegu terminu przedawnienia oraz roszczeń związanych z niezawarciem umowy przyrzeczonej. Według R. Sadlika ${ }^{59}$ strony umowy przedwstępnej nie muszą podawać terminu zawarcia umowy przyrzeczonej,

56 B. Wagner, Zakres swobody umów..., s. 164.

57 Por. wyrok SN z 5 września 2001 r., I CKN 214/99, OSP 2002 nr 4, poz. 57, s. 215.

58 Zob. wyroki SN: z 7 maja 2003 r., IV CKN 113/01, Legalis, nr 62101oraz z 27 stycznia 2000 r., II CKN 707/98, OSP 2000, nr 10, poz. 147.

59 R. Sadlik, Umowa przedwstepna..., s. 245. 
co jest wygodne zwłaszcza w tych sytuacjach, gdy jego oznaczenie jest zbyt utrudnione, a ponadto istnieje ustawowy mechanizm ustalania tego terminu.

\section{Podsumowanie}

Kończąc, należy wskazać, iż zawieranie umów przedwstępnych w stosunkach pracy w dalszym ciągu należy do rzadkości. Wynika to w szczególności z faktu, że strony wychodzą z założenia, iż ten sam cel, któremu ma służyć umowa przedwstępna, zrealizują poprzez zawarcie umowy o pracę i ustalenie w niej nawet bardzo odległego w czasie terminu rozpoczęcia pracy ${ }^{60}$. Pomijając jednak tę kwestię, dostrzegalny jest ogólny brak zainteresowania zawieraniem umów przedwstępnych. Z jednej strony, w dalszym ciągu wynika to z niskiej świadomości prawnej służb pracowniczych (kadrowych) na temat możliwości zawierania takich umów, z drugiej strony - z braku zapotrzebowania w stosunkach pracy na ten typ umowy. $Z$ reguły pracodawcy nie są zainteresowani zawieraniem umów przedwstępnych, z kolei siła negocjacyjna pracownika jest na tyle słaba, że nie jest on w stanie skłonić potencjalnego pracodawcy do zawarcia takiej umowy. Ponadto w dalszym ciągu umowy te są najczęściej zawierane w odniesieniu do osób, które zajmują, względnie będą zajmować, stanowiska kierownicze lub samodzielne i są poszukiwanymi specjalistami w jakiejś dziedzinie. W pozostałych przypadkach nadal najwłaściwszą formą zabezpieczenia przyszłego zatrudnienia pozostaje zawieranie umów o pracę z odległym w czasie terminem rozpoczęcia pracy. Takie bowiem umowy, zdaniem stron, wprowadzają jasność we wzajemnym statusie stron, albowiem umowa o pracę jest instytucją już ukształtowaną, a mechanizm jej działania - dobrze znany. Z kolei regulację w istocie cywilnoprawną postrzegają jako wprowadzającą pewne niejasności i mogącą być źródłem wątpliwości interpretacyjnych. Można jednak, z dużym stopniem prawdopodobieństwa, oczekiwać, iż sytuacja ta ulegnie ewolucji na skutek zmian zachodzących na rynku pracy, który - będąc do niedawna rynkiem pracodawców - ma szansę stać się wkrótce rynkiem pracowników.

Umowa przedwstępna powinna stanowić użyteczny instrument prawny pozyskiwania pracowników w zawodach deficytowych i w warunkach braku kandydatów do pracy o niezbędnych kwalifikacjach na lokalnym rynku pracy. Dla pracownika stwarza poczucie pewności zatrudnienia w przyszłości i pozwala na przygotowanie się do tej czynności poprzez załatwienie spraw osobistych i zawodowych, dla pracodawcy - warunki do przygotowania stanowiska pracy. 


\section{Bibliografia}

Bury B., Odpowiednie stosowanie w prawie pracy wybranych przepisów Księgi III Kodeksu cywilnego, Monitor Prawa Pracy 2007, nr 5.

Drozd E., Umowa przedwstępna a umowa przyrzeczona, Nowe Prawo 1973, 11.

Gersdorf-Giaro M., Umowa przedwstępna w prawie pracy, Państwo i Prawo 1979, 11.

Gersdorf M., Zawarcie umowy o prace, Warszawa 1985.

Gwiazdomorski J., Umowa przedwstępna w kodeksie zobowiązań, Czasopismo Prawnicze, t. XXX, Kraków 1936.

Kałuziński A., Pojęcie, funkcje, charakter prawny umowy o stypendium fundowane, Państwo i Prawo 1968, 8-9.

Kijowski A., Pracowniczy obowiązek gotowości do świadczenia pracy, Poznań 1978.

Kondracka A., Pojęcie i charakter prawny umowy przedwstępnej, Monitor Prawniczy 1999, 3.

Krajewski M., Umowa przedwstępna, Warszawa 2000.

Krajewski M., Wadliwości umowy przedwstępnej a umowa przyrzeczona, Monitor Prawniczy 2000, 5 .

Kruszewska J., Skutki prawne przyrzeczenia zawarcia umowy o prace, Przegląd Ustawodawstwa Gospodarczego 1979, 3.

Kurzych A., Odszkodowanie z tytułu niewykonania pracowniczej umowy przedwstępnej, Monitor Prawa Pracy 2010, 3.

Liszcz T., Zmiana zatrudnienia w wyniku porozumienia zakładów pracy, Nowe Prawo 1977, 5. Liszcz T., Prawo pracy, Warszawa 2009.

Malanowski A., Niektóre problemy prawne skierowania do pracy absolwentów szkół wyższych, Panstwo i Prawo 1966, 2.

Masewicz W., Glosa do uchwały SN z 22 kwietnia 1977 r., I PZP 5/77, OSN 1977, z. 10, poz. 180.

Mirończuk A., Glosa do wyroku SN z 2 października 1975 r., I PRN 21/75, OSPiKA 1976, nr 9 , poz. 167.

Muszalski W., Przedwstępna umowa o pracę czy zbędna konstrukcja prawna, Praca i Zabezpieczenie Społeczne 1999, 3.

Rudnicki G., Umowa przedwstępna, w: S. Rudnicki, Prawo obrotu nieruchomościami, Warszawa 1995.

Sadlik R., Umowa przedwstępna poprzedzająca zawarcie umowy o pracę, Monitor Prawa Pracy 2008, 5 .

Salwa Z., Rola umowy w kształtowaniu stosunku pracy, Państwo i Prawo 1977, 11.

Strzępka J., Umowy przedwstępne w obrocie uspołecznionym, Warszawa 1978.

Szewczyk H., Umowa przedwstępna w polskim prawie pracy, Z Problematyki Prawa Pracy i Polityki Socjalnej, Katowice 2001, 14.

Szubert W., Zarys prawa pracy, Warszawa 1976.

Święcicki M., Prawo pracy, Warszawa 1968.

Wagner B., Zakres swobody umów w pracowniczym stosunku pracy, Kraków 1986.

Zieliński T., Zarys wykładu prawa pracy, cz. II, Katowice 1978. 